\title{
HISTORISITAS DAN PERAN PONDOK PESANTREN SOMALANGU DI PESISIR SELATAN
}

\author{
Atabik \\ STAIN Purwokerto, Jl. A. Yani No. 40 A Purwokerto 53126 \\ E-mail: atabik.zuhdi@gmail.com \\ HP. +62-8122713447
}

Abstract:This paper reveals the Somalangu Islamic boarding school in Kebumen that has an important role for the people in southern coast of Java. Historically, the existence of the school becomes the starting point of Islam development there. In social transformation, the school fought against colonizer. Unfort unately the school was considered deviant when there was a conflict with the national army. Islamic force (AOI) that was led by KH Mshfudz Abdurrahman was accused to build an Islamic country and the misunderstanding made him killed. Meanwhile, KH Mahfudz Abdurrahman only wanted to fight against colonizer.

Abstrak: Tulisan ini berusaha untuk mengungkap tentang Pondok Pesantren Somalangu, di Kebumen yang memiliki peran penting dalam penyebaran Islam di Pesisir Selatan. Keberadaan dari Pondok Pesantren Somalangu menjadi pilar awal mula Islam di Pesisir Selatan apabila ditinjau dari aspek historis (awal berdirinya). Peranan Pondok Pesantren Somalangu dalam transformasi sosial muncul dalam wujud kepedulian untuk melawan penjajah. Hanya saja, peran dari Pondok Pesantren Somalangu dianggap menyimpang ketika tahun 1950an terjadi konflik dengan TNI. Angkatan Oemat Islam (AOI) yang dipimpin oleh KH Mahfudz Abdurrahman dianggap akan mendirikan negara Islam. Kesalahpahaman itu terjadi dan menjadikan KH Mahfudz Abdurrahman gugur. Padahal, maksud dari KH Mahfudz Abdurrahman hanya tidak mau meletakkan senjata apabila Indonesia masih dalam pengaruh Belanda. Tulisan ini dimaksudkan untuk meluruskan sejarah yang timpang.

Kata Kunci: Pondok Pesantren, Somalangu, KH Mahfudz Abdurrahman, AOI, dan Islam. 


\section{A. Pendahuluan}

Peristiwa sejarah Islam di Jawa sejatinya terbentuk dengan adanya pondok pesantren yang memegang peranan begitu penting. Hal ini karena persebaran Islam dimulai dari pondok pesantren yang mampu melahirkan tokoh-tokoh intelektual (Steenbrink, 1986), yang juga kemudian membuat pondok pesantren kecil di desa-desa (Geertz, 1983: 4). Selain itu, Islam di Nusantara juga turut berperan penting dalam usaha melawan penjajah dengan pergerakan-pergerakan terorganisasi berdasarkan bimbingan dan arahan kiai. Dengan demikian, dapat disimpulkan bahwa historistas Islam di tanah Jawa ini ditandai oleh peranan pondok pesantren dalam membangun peradaban baru di masyarakat.

Pada ranah sosial, kiranya cukup penting untuk melihat relasi sosial antara kiai dengan santri, santri dengan santri, serta lingkup pondok pesantren dengan masyarakat di sekitarnya. Hal ini karena di lingkup Pondok Pesantren Al-Kahfi Somalangu Kebumen ada relasi yang dibangun dalam satu kesatuan yang kompleks dengan masyarakat Islam di Kebumen dan sekitarnya. Pondok pesantren yang berada di tengah-tengah masyarakat juga memiliki hubungan timbal balik dengan masyarakat sekitarnya, bahkan memberikan efek bagi masyarakat di sekitarnya. Satu hal yang meyakinkan dalam ranah sosial ini bahwa relasi bolak-balik antara individu dengan sekitarnya adalah individu itu sendiri menjadi bagian dari satu kesatuan. Ada usaha untuk mendeskripsikan realitas sosial dengan memahami pemikiran dan pengetahuan subjek-objek, yakni tidak hanya mempelajari masyarakat melainkan juga mengetahui masyarakat dengan berusaha untuk menemukan hal baru, sekaligus mengevaluasi kebenaran yang tersembunyi.

Berdasarkan paparan tersebut, menarik kiranya untuk melacak jejak KH Mahfudz Abdurrahman dalam sejarahnya di Pondok Pesantren Somalangu (Pondok Pesantren Al-Kahfi), di Kebumen. Dalam hal ini, KH Mahfudz Abdurrahman selain sebagai kiai juga berhasil sebagai tokoh yang mampu melakukan pergerakan sosial juga mampu menyebarkan Islam dengan baik, dan turut serta dalam perlawanan penjajah. Hanya saja, KH Mahfudz Abdurrahman beserta Angkatan Oemat Islam (AOI) (Kuntowijoyo, 2008: 16) dianggap menyimpang dan melawan negara ketika tidak mau meletakkan senjata selama negara dalam sistem RIS yang masih dalam pengaruh Belanda. Tulisan ini berusaha untuk mengupas data-data sejarah yang selama ini tidak terungkap sehingga sejarah yang timpang dapat diluruskan. 


\section{B. Pondok Pesantren}

Pesantren sebenarnya berasal dari kata santri, yang kemudian mendapat awalan pe-an sehingga apabila disusun pesantrian, namun dalam tata tulis Jawa huruf /a/ dan /i/ bila bertemu menjadi /e/ (Fuad \& Suwito NS, 2009: 6). Pesantren artinya adalah kumpulan santri, adapula yang mengartikan proses menjadi santri (orang yang berbudi luhur). Dalam hal ini, apabila tergabung antara kata "pondok" (dalam bahasa Arab berarti 'tempat tidur') dan "pesantren" menjadi "pondok pesantren", maka berarti tempat dari kumpulan santri yang sedang belajar untuk mendapatkan ilmu yang luhur (Dhofier, 1994:78). Tempat dari para santri ini sifatnya sementara waktu, yakni ketika sedang belajar saja. Santri membutuhkan tempat karena mereka berasal dari daerah yang jauh sehingga membutuhkan tempat tersendiri untuk memfokuskan belajarnya.

Pondok pesantren menjadi tempat dari para santri untuk mendapatkan pengetahuan dan ajaran agama dari seorang kiai. Dalam praktik pengajarannya, pondok pesantren memiliki konsep pengajaran agama Islam berdasarkan kepada al-Qur' an dan Hadis, juga kita-kitab Islam seperti Safīnah, Aqā'id, Kitab Kuning, dan kitab lainnya yang merupakan karya dari tokoh Islam. Di pondok pesantren, membaca al-Qur'an menjadi pembelajaran utama dan dasar bagi seorang santri untuk bisa membaca dengan baik dan benar. Hal ini dilanjutkan dengan pembelajaran lainnya, bahkan ada juga pondok pesantren yang membekali para santri dengan materi umum seperti bertani dan beternak dengan hasil dinikmati bersama saat hari-hari besar saat Mulud atau hari raya.

Pondok pesantren memiliki peranan dalam hal sebagai "agen perubahan" dengan membentuk pembelajaran pada santri, maupun masyarakat yang ada di sekitarnya (Fuad \& Suwito NS, 2009: 20). Masuknya Islam di Nusantara mengarahkan pada tata cara peradaban baru melalui pakaian yang menutup aurat, hidup bersuci, disiplin, cara membangun keluarga, pertanian, peternakan, bahkan hingga pertumbuhan ekonomi. Pondok pesantren sebagai lembaga pendidikan memberikan pengaruh yang sangat besar pada pengetahuan masyarakat. Pada zaman sebelum Islam, sebagian penduduk di Jawa hanya memakai pakaian ala kadarnya saja, dan hanya pada bagian tertentu, namun sejak adanya Islam mengajarkan untuk bagian țahārah dan menutup aurat saat shalat menjadikan orang di Jawa terbiasa dengan pakaian yang rapat. Dari sejarah ini, dapat dipahami bahwa sesungguhnya keberadaan Islam membawa pembaharuan bagi masyarakat di sekitar. Adapun yang lebih penting lagi adalah peranan pondok pesantren dalam keterlibatan pada bangsa dan negara, yakni dengan melahirkan tokoh-tokoh penting untuk pengambil kebijakan. Dapatlah 
dicermati juga peranan tokoh Islam dalam Pancasila, yaitu "ketuhanan Yang Maha Esa".

Dalam perkembangan Islam di Nusantara, pesantren memiliki peranan yang cukup penting sebagai agen perubahan dan pembentukan pola pikir masyarakat (Geertz, 1983). Ulama yang datang ke Nusantara mengajarkan Islam dengan memberikan pendidikan dan pemahaman untuk hidup dalam peradaban yang lebih baik. Ulama (baik yang datang dari Arab dan Persia, India, maupun Cina) ternyata banyak membuat pondok pesantren untuk memberikan arahan hidup dalam keimanan dan cara menjalani hidup sehari-hari yang dipenuhi berkah. Dalam fakta sejarah diketahui bahwa Syaikh Maulana Malik Ibrahim membangun pesantren dengan mendidik orang-orang di sekitarnya untuk mempelajari agama, tata hidup sehari-hari, dan belajar ilmu kanuragan. Hal ini tidak lepas dari konsep ajaran Islam yang sebagai petunjuk sebagaimana tertuang di dalam al-Qur'an dan Hadis, yang ditransformasikan dengan budaya lokal. Boleh dikatakan bahwa pesantren menjadi tempat pencerahan bagi masyarakat dalam jaringan intelektual sehingga menjadi pembaharuan atas dimensi lokal Nusantara.

Data yang diungkapkan oleh Steenbrink (1986: 10-14), pondok pesantren telah membentuk model pendidikan keagamaan yang diberikan secara kelompok maupun individual yang disesuaikan dengan konteksnya. Usaha untuk menyampaikan ajaran Islam dengan mengacu pada konteks yang ada di Nusantara dapat terlihat pada penggunaan bahasa yang menggunakan huruf Arab Pegon. Dalam hal ini, ada wujud transformasi antara bahasa Arab dengan bahasa Melayu sehingga ajaran Islam bisa diterima di Nusantara. Selain itu, pesantren juga tetap mengambil nilai-nilai luhur di masyarakat yang memang selaras dengan ajaran Islam sehingga secara ideologis dapat membentuk "struktur kesadaran" untuk diterima dengan jiwa yang lapang.

Peranan pondok pesantren sebagai agen perubahan juga terlihat dalam pergerakan sosial. Tradisi pembelajaran yang berjalan di pondok pesantren lamakelamaan membentuk sistem dan herarki yang memiliki hubungan dengan masyarakat dan negara. Said (2011: 182) mengungkapkan bahwa pondok pesantren dalam kiprah yang cukup panjang telah membuktikan eksistensi dan kiprah sebagai dinamisator dalam perjuangan dan pembangunan. Hal ini dapat juga dilihat peranan pondok pesantren sejak masa Kerajaan Demak hingga pondok pesantren semasa perjuangan bangsa melawan penjajah. Dalam hal ini, pondok pesantren memunculkan tokoh-tokoh penting yang turut berperan serta dalam pengabdian masyarakat dan negara. Konsep yang melandasi iktikad seperti itu adalah tingkat keimanan dan ketakwaan kepada Allah, yang memulai 
landasan hidup untuk mengabdi pada Tuhan, kepada diri sendiri, kepada keluarga, kepada masyarakat, dan kepada negara. Adanya ajaran untuk turut berbakti pada masyarakat dan negara adalah perwujudan dari konsep muamalah sebagai perluasan peradaban.

Kehadiran pesantren sebagai lembaga pendidikan pada akhirnya juga memunculkan tokoh-tokoh intelektual penting dalam sejarah bangsa. Hal ini menandakan bahwa keberadaan pondok pesantren itu sendiri berhasil mengubah paradigma masyarakat. Tokoh intelektual tersebut adakalanya juga membentuk pondok pesantren baru di daerahnya sebagai wujud transformasi pengetahuan untuk turut mendakwahkan ajaran Islam.

Keberadaan tokoh di pondok pesantren menjadi sangat penting karena sebagai inspirator, yang sejalan dengan pepatah "guru: digugu lan ditiru (dipercaya kata-katanya dan dicontoh perbuatan baiknya)." Dasar untuk menjadikan tokoh di pesantren (baca: kiai) sebagai inspirator tidak lain juga mengacu pada ajaran Islam yang menjadikan Nabi Muhammad SAW sebagai inspirasi hidup. Dalam ajaran, disebutkan bahwa yang pantas menjadi teladan dalam hidup adalah Nabi, sahabat, tabi'in, awliā', dan ulama. Selain itu juga, biasanya para kiai adalah orang yang telah memiliki bekal pengetahuan (baik agama maupun umum) sehingga sering menjadi pemecah solusi at as berbagai permasalahan di masyarakat (Fuad \& Suwito NS, 2009). Adapun hal lain yang menjadikan kiai dipandang sebagai tokoh penting adalah kerangka berpikir dari masyarakat Nusantara (Jawa pada khususnya) yang selalu memandang bahwa tokoh punya kelebihan dalam ilmu mistis dan mampu menjalin hubungan dengan dimensi lain (Suwito NS, 2011). Oleh karena itulah, kiai memiliki peranan yang cukup penting bagi masyarakat yang ada di sekitarnya, baik di desa maupun di kota, serta dihormati.

Pesantren didirikan oleh seorang kiai setelah mendapatkan ilmu pengetahuan tentang Islam dari gurunya. Semula, ia adalah seorang santri, namun karena dianggap telah menyerap banyak pengetahuan dan harus diamalkan, juga diajarkan, maka ia mendirikan pondok pesantren di daerah tertentu (baik di daerah asal kelahirannya, maupun di daerah yang membutuhkan bimbingan ajaran Islam). Kiai dan pesantren memiliki ikatan yang sangat kuat (Dhofier, 1994). Keberadaan pesantren di suatu daerah tidak lepas dari eksistensi seorang kiai yang berwibawa. Boleh juga dikatakan bahwa kiai adalah pusat dari semua pengetahuan yang ada di pondok pesantren. Kiai menjadi sumber berkembang atau tidaknya sebuah pondok pesantren tersebut. 


\section{Kiai dan Pesantren}

Istilah kiai ditujukan sebagai sebutan untuk orang yang memiliki pengetahuan agama Islam (Dhofier, 1994; Steenbrink, 1984). Predikat ini biasanya diberikan oleh masyarakat karena orang tersebut memiliki pengetahuan, wawasan, dan pemahaman agama yang diajarkan kepada masyarakat sekitar. Beberapa orang kadang membedakan antara kiai dengan ulama. Ulama dipahami sebagai seseorang yang memiliki ilmu pada khazanah tertentu dengan tingkat amaliah juga dalam kehidupan sehari-hari. Seiring dengan perkembangan, istilah kiai melekat pada orang-orang yang mendirikan pondok pesantren at au orang-orang yang memiliki pengetahuan agama Islam dan mendirikan pondok pesantren untuk mengamalkan pengetahuan, wawasan, dan pemahaman agama kepada masyarakat. Silang wacana sering terjadi sehingga sering kedua istilah itu menjadi melekat, namun perbedaan berdasarkan pada Kamus Besar Bahasa Indonesia dapat dicermati bahwa kiai berfokus pada bidang agama Islam sebagai pengajarannya, namun ulama dipahami sebagai orang yang cerdik dan guru dalam ilmu lain.

Bagi masyarakat, keberadaan seorang kiai dianggap sangat penting untuk menjawab persoalan hidup yang berkaitan dengan agama (Steenbrink, 1984). Kiai diangap sebagai orang yang mengentahui di berbagai bidang dengan berdasar kepada al-Qur'an dan Hadis. Kata-kata dari seorang kiai dianggap memiliki makna atas setiap permasalahan yang sedang dihadapi. Dengan adanya pengaruh semacam ini, seorang kiai menjadi titik pusat kebenaran atas realitas yang sedang mereka hadapi. Oleh karena itu, kiai menjadi tokoh karena pengetahuan, wawasan, dan pemahaman agama Islam bagi masyarakat di sekitarnya.

Kata-kata dari seorang kiai dengan berdasar ada al-Qur'an dan Hadis menjadi titik kebenaran yang diyakini. Dalam kaitan ini, wajar apabila seorang kiai dapat menggerakkan masyakat di sekitarnya. Belum lagi, realitas kosmos yang secara metafisis berada di dalam diri seorang kiai sehingga keberadaanya dapat menjadi arena perubahan sosial (Kuntowijoyo, 1996).

Kiai, dalam pengajaran agama Islam, tidak menginginkan adanya perbudakan, dan penindasan. Berdasarkan pada konsep ini, umat Islam yang saat itu berakar pada pondok pesantren memiliki tekad untuk melakukan perlawanan kepada penjajah. Oleh karena itu, eksistensi pondok pesantren dalam sejarah juga memberikan andil yang cukup besar dalam kemerdekaan (Zuhri, 2010: 30). Mereka turut serta dalam perang kemerdekaan melalui pengabdian (Fuad \& Suwito NS, 2009). Para santri dengan dipimpin oleh kiai melakukan perlawanan kepada penjajah sebagai bentuk kesadaran nasionalisme, yang juga menegaskan bahwa hidup di dunia ini tidak hanya untuk berdoa dan bersujud kepada Tuhan 
saja. Banyak perjuangan gerilya dari rakyat jelata yang dimulai dari pondok pesantren, namun hal ini tidak mendapatkan sorotan oleh sejarah. Sebagai contoh, dapat dilihat juga pada KH Hasyim Asy'ari di Jombang yang berusaha dengan gigih untuk memperjuangkan kemerdekaan dan berusaha untuk menjadikan tidak ada penjajahan.

\section{KH Mahfudz Abdurrahman}

Selama ini, pandangan kebanyakan orang mencurahkan perhatian Islam ke pesisir utara. Laut yang lebih tenang dan hubungan perdagangan di masa lampu yang berinteraksi secara kompleks membuat pesisir utara lebih populer dalam sejarah. Dalam pandangan Geertz (1983), bahwa kalangan santri lebih muncul di pesisir utara. Hal ini juga dapat terlihat dalam titik garis persinggungan Walisongo di Jawa (Ridwan dkk, 2007: 16).

Namun demikian, di Pesisir Selatan juga mengalami pembaruan dalam persebaran Islam. Islam di Pesisir Selatan dapat terlihat dalam lintas jalur perkembangan Islam melalui pondok pesantren kecil, yang kemudian menjadi besar seiring dengan bertambahnya jumlah masyarakat itu sendiri. Kebanyakan orang menilai bahwa Islam di Pesisir Selatan memiliki paradigma yang lebih dekat ke arah mistis dengan tasawuf sebagai bagian penting untuk dipelajari. Hal ini karena orang-orang di Pesisir Selatan lebih tertutup dan memiliki cara pandang yang lebih teologis.

Somalangu, nama sebuah kampung di Kebumen, memiliki sejarah yang lebih tua daripada Kota Kebumen. Dari beberapa macam versi sejarah menyebutkan bahwa kata Somalangu bermula dari awal perkembangan Islam di Jawa. Ada yang menyebutkan bahwa Somalangu merupakan pemberian dari Kerajaan Demak (meskipun diragukan kebenarannya). Beberapa orang lebih percaya bahwa Somalangu mulai ada pada masa keberakhiran dari Kerajaan Pajang yang juga bertepatan dengan berdirinya Kerajaan Mataram Islam oleh Panembahan Senopati (Sudibyo, 2012). Apabila merujuk pada awal pendiri Somalangu, yakni Syaykh al-Sayyid Abd al-Kahfi al-Hasani (yang juga disebut sebagai Syaykh al-Sayyid 'Abd al-Kahfi al-Awwāl), yang sampai sekarang sudah 16 generasi penerus, maka bisa dikatakan bahwa pondok pesantren ini sudah ada sekitar 600 atau 800 tahun lalu. Hal ini sejalan dengan perkembangan awal Islam ke Jawa oleh para ulama dari Arab, maupun Gujarat. Hanya saja, nama Somalangu bisa muncul atau berubah seiring dengan perkembangan dan pengaruh dari kerajaan pada masa itu, bahkan setelahnya. Yang jelas, Somalangu telah membentuk sistem pengetahuan Islam, jauh sebelum nama Kebumen menjadi populer. Hal ini karena popularitas nama Kebumen itu semenjak 
adanya pembagian kadipaten oleh Kerajaan Mataram. Hal ini sebagaimana dinyatakan oleh Idrus, bahwa

Pondok pesantren di Somalangu Kebumen merupakan Pondok Pesantren yang terhitung cukup tua keberadaannya. Pondok pesantren ini telah ada semenjak tahun $1475 \mathrm{M}$. Adapun tahun dan waktu berdirinya dapat kita ketahui diantaranya dari Prasasti Batu Zamrud Siberia (Emerald Fuchsite) berbobot $9 \mathrm{~kg}$ yang ada di dalam Masjid Pondok Pesantren tersebut. Menurut keterangan yang dihimpun oleh para ahli sejarah, ciri khas pondok pesantren yang didirikan pada awal permulaan Islam masuk di Nusantara adalah adanya sebuah masjid di dalam lingkungan pondok pesantren itu. Jadi pendirian masjid ini merupakan bagian dari pendirian sebuah pesantren (Idrus, 2012: 46).

Keberadaan Pondok Pesantren Somalangu di daerah Kebumen memberikan pengaruh yang cukup besar dalam perkembangan Islam. Hal ini karena kebanyakan dari Walisongo lebih banyak menyebarkan Islam di pesisir utara. Batas perairan selatan dengan tata ruang yang saat itu masih kental dengan pengaruh Hindu membuat pandangan mistis masyarakat masih tetap ada. Pengaruh Hindu yang begitu besar membuat Syeikh As-Sayid Abdul Kahfi AlAwwal harus mendirikan pondok pesantren karena bila tidak menetap di daerah tersebut, maka keyakinan masyarakat akan berubah kembali. Keberadaan Pondok Pesantren Somalangu memberi nuansa tauhid pada masyarakat untuk meyakini Allah sebagai sang Pencipta. Dalam kaitan ini, Kiai Pesantren lebih mementingkan mendidik santri, memberikan pengetahuan agama melalui kitabkitab, mengurusi persoalan keseharian dan memimpin ritual-ritual. Hal ini karena masyarakat harus diarahkan pada ajaran fiqih yang benar untuk menghindari kekeliruan.

Pendirinya adalah Syaykh al-Sayyid Abd al-Kahfi al-Hasani dengan nama asli Sayyid Muhammad 'Ișam al-Ḥasani. Beliau semula merupakan seorang tokoh ulama yang berasal dari Hadharamaut,Yaman. Lahir pada tanggal 15 Sya'ban 827 H di kampong Jamhar, Syihr. Dia datang ke Jawa tahun $852 \mathrm{H}$ atau 1448 M pada masa pemerintahan Prabu Kertawijaya Majapahit atau Prabu Brawijaya I (1447 -1451). Setelah 27 tahun pendaratannya di tanah Jawa, Syaykh al-Sayyid Abd al-Kahfi al-Ḥasani barulah mendirikan Pondok Pesantren alKahfi Somalangu, Kebumen. Di Somalangu inilah, beliau akhirnya bermukim dan pesantren yang didirikannya kemudian hari dikenal dengan nama Pondok Pesantren Al-Kahfi Somalangu Kebumen. Syaykh al-Sayyid Abd al-Kahfi alHasani wafat pada malam Jum'at, 15 Sya'ban $1018 \mathrm{H}$ atau bertepatan dengan tanggal 12 November 1609 M. Jasad beliau dimakamkan di bukit Lemah Lanang, Somalangu, Kebumen. Dialah orang pertama yang dimakamkan di tempat tersebut (Supriyanto, 2012). 
Satu hal yang menjadi landasan penting mengenai Pondok Pesantren Somalangu (Pondok Pesantren Al-Kahfi) dan kisah KH Mahfudz Abdurrahman adalah buku dari Kuntowijoyo yang berjudul Paradigma Islam: Interpretasi Untuk Aksi yang diterbitkan oleh Mizan pada tahun 2008. Dalam buku ini, dipaparkan mengenai kehidupan KH Mahfudz Abdurrahman yang memiliki gagasan cukup menarik dalam membentuk Angkatan Oemat Islam (AOI), sekaligus mengungkap gerakan yang dilakukan. Fokus pandangan dari Kuntowijoyo ini mengarah pada gerakan dan pemikiran yang mampu mempengaruhi lingkungan sekitarnya (Kuntowijoyo, 2008).

Dalam sejarah, sebagaimana disebutkan oleh Kuntowijoyo (2008), disebutkan bahwa KH Mahfudz Abdurrahman (yang memiliki nama asli Syaykh Asal-Sayyid Mahfudz al-Hasani) adalah tokoh penting di kalangan orang Islam di Jawa, khususnya Jawa Tengah, Pesisir Selatan. Beliau adalah salah satu tokoh penting dalam perjalanan Pondok Pesantren Somalangu di Kebumen, yang menempuh jalan keilmuan dari lingkup keluarga, Pesantren Termas, kemudian belajar ke Pondok Pesantren Watucongol, Muntilan, serta berguru juga pada Syaykh As-al-Sayyid Sa' id bin Muhammad Babașal di daerah Misfalah. Selain mengajarkan agama Islam melalui mengaji, KH Mahfudz Abdurrahman juga memiliki rasa kepedulian yang tinggi terhadap bangsa melalui Pondok Pesantren Somalangu (yang sebenarnya memiliki nama Pondok Pesantren Al-Kahfi, dan mulai ada sejak ada sejak 1475 M). Dalam sejarah, Pondok Pesantren Somalangu juga melakukan pergerakan sosial dengan melatih para santri dan masyarakat dalam mengusir pasukan Belanda dengan nama Angkatan Oemat Islam (AOI). Peran KH Mahfudz Abdurrahman cukup besar dengan menjadikan Somalangu sebagai tempat rapat untuk Angkatan Oemat Islam (AOI) dan membentuk kepedulian bersama (Kuntowijoyo, 2008: 25).

Berdasarkan peran dari KH Mahfudz Abdurrahman, Angkatan Oemat Islam (AOI) menjadi dikenal sebagai pejuang yang gigih dan rela berkorban demi tanah air. Mereka bertempur dengan senjata seadanya, namun semangat dan tekad tak pernah hilang sedikitpun dan selalu membara di dalam jiwa, dan hal ini terus dilakukan hingga Agresi Militer I dan Agresi Militer II. Pengaruh KH Mahfudz Abdurrahman cukup besar, bahkan ketika terjadi perundingan damai antara RI dan Belanda yang mencapai kata sepakat, maka dengan seketika itu KH Mahfudz Abdurrahman berhasil menjadikan Kebumen penuh dengan ketenangan. Selain itu, menurut Kuntowijoyo (2008), KH Mahfudz Abdurrahman melalui Pondok Pesantren dan Angkatan Oemat Islam (AOI) memberikan dakwah dan pembelajaran pada masyarakat di Kebumen dan sekitarnya. Ada 
arahan secara moral dan budi pekerti dengan pengembangan semangat nasionalisme.

Catatan mengenai Pondok Pesantren Somalangu mulai terpampang luas pada masa terjadinya peristiwa Angkatan Oemat Islam (AOI) yang menggetarkan pada tahun 1950. Jauh sebelumnya, tidak banyak cat at an mengenai kiprah dari Pondok Pesantren Somalangu meskipun beberapa santri dari Somalangu telah andil dalam Perang Dunia I, yang membela Kesultanan Utsmaniyyah Turki. Adapun di tanah air sendiri, para santri dari Pondok Pesantren Somalangu juga turut melawan Penjajah Belanda yang bertindak sewenang-wenang. Pondok Pesantren Somalangu tercatat dalam sejarah Indonesia tatkala 1945, yakni peristiwa Angkatan Oemat Islam (AOI). Peristiwa ini cukup menggetarkan karena telah terbentuk laskar dengan anggota sekitar 10.000 orang. Mereka berasal dari Kebumen, Purbalingga, Wonosobo, dan Purworejo, dengan pusat di Pondok Pesantren Somalangu. Laskar dengan nama "Tarekat Syadzaliyah" ini berada di bawah pimpinan Syekh Mahfudz Abdurrahman dengan julukan "Rama Pusat", yang kemudian bergabung dengan pasukan Hizbullah-Sabilillah.

Dalam masa ini, Pondok Pesantren Somalangu tidak hanya mengajarkan agama saja, tetapi juga turut membela negara. Islam tidak hanya mengajarkan ilmu untuk diri sendiri. Islam juga memiliki ajaran-ajaran sosial untuk melindungi sesama dan berusaha untuk menebarkan perdamaian hidup. Segala hal yang bertentangan dengan nilai-nilai kemanusiaan haruslah diarahkan dengan usaha ucapan maupun tindakan. Mereka telah menyadari pentingnya arti kemerdekaan dan hidup dalam kemerdekaan. Berdasar pada sudut pandangan dan nilai-nilai tersebut, ulama-ulama di Indonesia berhasil mempertahankan proklamasi kemerdekaan 17 Agust us 1945, juga turut berperan serta dalam melawan tentara Inggris dan NICA di Palagan Ambarawa dan peristiwa 10 November di Surabaya.

Ketangguhannya teruji ketika AOI sebagai badan terbesar berhasil mencegah Agresi Militer Belanda I pada tanggal 21 Juli 1947 yang bergerak ke Yogyakarta sehingga memaksa Panglima NICA, yaitu Jendral Spoor dan Gubernur Jendral Hindia Belanda yang baru Dr. H.J van Mook, membuat garis demarkasi di Sungai Kemit-Gombong. Akan tetapi garis van Mook ini bobol dalam kampanye militer Doorstot naar Djokdja alias Agresi Militer II pada tanggal 18 Desember 1948. Meski berhasil menguasai Kebumen dengan bermarkas di Gedung Gembira (saat ini berada di dekat Stasiun KA Kebumen), Pasukan elit Gajah Merah dan Anjing Hitam NICA tidak pernah bisa menganeksasi Somolangu, meskipun jarak pondok tersebut hanya 
berjarak sekitar $2 \mathrm{Km}$ dari jalan utama Kebumen - Purworejo (Supriyanto, 2012).

Semenjak peristiwa itu, AOI mengalami perselisihan dengan TNI. Perselisihan ini terjadi dengan berbagai macam sudut pandang. TNI yang banyak didominasi oleh para Priyayi Jawa sering tidak sejalan dalam nilai-nilai. Begitu juga niatan dari AOI yang sering sering bertiak "Allahu Akbar" dianggap menjadikan identitas mereka mudah dilacak oleh NICA. Pada puncaknya, ada sekitar 6000 ulama dibantai. Semenjak itu, AOI sering tidak sejalan hingga dianggap akan membuat Negara Islam pasca Konfrensi Meja Bundar di Bandung. Aksi seranga menyerang antara TNI dan anggota Batalyon Lemah Lanang pun terjadi hingga menjadikan perang saudara. Bahkan, AOI dikatakan terhubung dengan DI/TII yang berada di bawah kepemimpinan Kartosuwiryo. Perang senjata antara TNI di bawah kepemimpinan Ahmad Yani melawan Batalyon Lemah Lanang dan Pasukan Kuda Putih tidak dapat dielakkan lagi sehingga banyak ulama dari Somalangu yang meninggal dunia, termasuk Syekh Makhfudz (yang tertembak di Gunung Selok (Srandil) Cilacap, Jawa Tengah.

Pondok Pesantren Somalangu mengalami duka yang mendalam. Semenjak peristiwa ini, tak banyak masyarakat yang peduli. Pondok Pesantren Somalangu menjadi kecil dan hanya tinggal beberapa generasi. Semenjak peristiwa ini juga, mereka tidak lagi terlibat secara aktif dalam tata pemerintahan Orde Baru. Mereka kembali lebih memfokuskan pada pengarajaran agama Islam dan memimpin ritual dalam kehidupan sehari-hari.

Sampai sekarang, di Pondok Pesantren Somalangu hanyalah satu desa yang dikenal dengan nama Sumberdi. Desa ini terletak di 5 kilometer dari Kota Kebumen. Desa Sumberdi merupakan gabungan dari desa Semlangu Wetan, Semlangu Kulon, dan Kemejing. Sampai sekarang, desa ini masih khas dengan area yang asri oleh rindang pepohonan. Nilai-nilai tradisi, religius, dan ekologi pedesaan masing sangat kental, sekalipun tak jauh dari jalan besar CilacapYogyakarta. Jika berjalan menuju Pondok Pesantren Somalangu, masih terpampang dengan jelas rumpun bambu yang rindang dan senantiasa bertahlil ketika diterpa angin, juga sawah-sawah dengan padi yang senantiasa tafakur. Dalam hal ini, dapat dikatakan bahwa Somalangu telah menjaga tata lingkungan dalam sejarah yang cukup panjang.

Teori etnografi mengungkapkan makna tindakan dari kejadian sejarah di Pondok Pesantren Al-Kahfi Somalangu Kebumen. Menurut James P. Spradly (2006: 7-10), bahwa masyarakat memiliki pengetahuan yang tersembunyi dalam ranah laku, emosi, dan permasalahan, yang kesemuanya itu membutuhkan interpretasi. Hal ini karena setiap perwujudan dari manusia selalu 
memiliki makna yang dalam keadaan tertentu memberikan efek pada lingkungan yang ada di sekitarnya. Masyarakat di Kebumen sendiri saat ini dikenal sebagai daerah santri, adapun keberadaan dari KH Mahfudz Abdurrahman menjadi sosok legendaris. Dalam hal ini, arahan untuk mengetahui fakta-fakta historis, juga membutuhkan pandangan masyarakat secara kualitatif pada orang-orang tertentu. Dalam pandangan Spradly lebih mendalam, dijelaskan bahwa masyarakat pembaca hendaknya memberikan tafsiran atas struktur sosial yang juga masuk dalam ranah kebudayaan dari Pondok Pesantren Al-Kahfi Somalangu Kebumen. Bagaimana pun juga, pola kehidupan dari Pondok Pesantren Al-Kahfi Somalangu Kebumen dalam masyarakat yang menstruktur dapat menjadi budaya.

Sampai sekarang ini, kisah mengenai Pesantren Somalangu, Kebumen begitu legendaris di kalangan umat Islam mengingat peranan dalam sejarah yang begitu gigih melawan penjajah dengan Angkatan Oemat Islam. Riwayat dari KH Mahfudz Abdurrahman menjadi legenda yang seolah-olah tetap terngiang dan seolah-olah tetap hadir. Oleh karena itu, pihak keluarga Pondok Pesantren Somalangu selalu mengingat dan mencatat riwayat hidup KH Mahfudz Abdurrahman. Begitu juga dengan masyarakat Islam di Kebumen dan sekitarnya yang selalu memandang KH Mahfudz Abdurrahman sebagai sosok mulia yang pernah ada dalam penyebaran Islam.

\section{E. Simpulan}

Dari pembahasan mengenai sejarah dari Pondok Pesantren Somalangu yang memiliki peranan besar dalam transformasi Islam di Pesisir Selatan, maka ada beberapa hal yang dapat disimpulkan. Pertama, Pondok Pesantren Somalangu memiliki peran edukatif di masyarakat sehingga mampu menjadi agen perubahan di Pesisir Selatan. Kedua, Pondok Pesantren Somalangu memiliki semangat nasionalisme yang tinggi. Hal ini dibuktikan dengan turut sertanya mereka dalam perlawan terhadap penjajah yang ingin merebut kembali tanah air ini. Ketiga, ada kesalahpahaman antara TNI dengan AOI yang dipimpin oleh KH Mahfudz Abdurrahman (yang berpusat di Somalangu) karena tidak mau meletakkan senjata dengan alasan bahwa Indonesia masih dalam pengaruh Belanda sehingga terjadi konflik. Keempat, semenjak peristiwa tahun 1950, Pondok Pesantren Somalangu lebih memfokuskan pada pengajaran agama Islam dan memimpin ritual dalam kehidupan sehari-hari yang berkaitan dengan tata kemasyarakatan. 


\section{Daftar Pustaka}

Fahmi, Akhmad Khoerul. 2013. "Biografi KH. Mahfudz Abdurahman Somalangu Kebumen" dalam manuskrip. Jakarta: Puslitbanglektur dan Khazanah Keagamaan Kementerian Agama Republik Indonesia.

Geertz, Clifford. 1983. Abangan, Santri, dan Priyayi dalam Masyarakat Jawa. Jakarta: Pustaka Dunia.

Idrus, Muhammad. 2012. "Dinamika Kehidupan Tarekat Syadziliyah di Pondok Pesantren al-Kahfi Somalangu Sumberadi Kebumen" Skripsi. Semarang: Fakultas Ushuludin, IAIN Walisongo.

Kuntowijoyo. 2008. Paradigma Islam: Interpretasi Untuk Aksi. Bandung: Mizan.

Said, Hasani Ahmad. 2011. "Meneguhkan Kembali Tradisi Pesantren di Nusantara" dalam Jurnal Ibda' Vol. 9. No. 2 Juli-Desember 2011. Purwokerto: P3M STAIN Purwokerto.

Spradley, James D. 2006. Metode Etnografi. Yogyakarta: Penerbit Tiara Wacana.

Subandi, Achmad. "Pesantren dan Perguruan Islam Al-Kahfi Somalangu Kebumen", (online), (http://sejarah.kompasiana.com/2010/10/08/pesantrendan-perguruan-islam-alkahfi-somalangu-kebumen-283419.html diunduh 18 Oktober 2013)

Sudibyo, Ma'rufin. 2012. "Sejarah Somalangu: Pahlawan Bangsa yang Dianggap Musuh Negara dan Pemberontak" dalam http://marsikin. multiply.com/journal/item/9?\&show_interstitial=1\&u=\%2Fjournal \%2Fitem diakses pada 27 Juli 2014.

Steenbrink, Karel A. 1986. Pesantren, Madrasah, Sekolah: Pendidikan Islam dalam Kurun Modern. Jakarta LP3ES.

Supriyanto. 2012. "Sejarah Somalangu" dalam Pelatihan Jurnalistik Ramadhan 2012 di Pondok Pesantren Al-Kahfi Somalangu, sarasehan Jurnalistik Ramadlan 2012.

Tjandrasasmita, Uka. 2000. Pertumbuhan dan Perkembangan Kota-Kota Muslim di Indonesia. Kudus: Menara Kudus.

Thohir, Mudjahirin. 2006. Orang Islam Jawa Pesisiran. Semarang: Fasindo Press.

Widianta, Danar. 2014. “Angkatan Oemat Islam 1945-50: Studi tentang Gerakan Sosial di Kebumen” dalam Jurnal Sejarah Vol. 6 No. 1 Agustus 2004. 